Fighting austerity:

\title{
Why after 80 years the General Theory is still relevant today*
}

Maria Cristina Marcuzzo ${ }^{\dagger}$

\begin{abstract}
The guiding spirit of the Keynesian Revolution is that full employment is a goal which can be pursued not by following the free market rules, but by reshaping them by means of public intervention. This message was widely accepted for thirty years as from the end of the Second World War by all the advanced countries which actively engaged in full employment and welfare policies, and subsequently abandoned with the neo-liberal Restoration which saw the dogmas of individualism and de-regulation prevailing. In reclaiming the topical importance of the General Theory, we should take into consideration the changed circumstances of today's world when compared to those of twenty - let alone eighty - years ago, although there are notable similarities between the Great Depression of the 1930s - Keynes's world - and our contemporary crisis. However, his prescription for a better society is still relevant: it lies in setting rules and limitations in the market arena, not letting individual self-interest prevail, and putting some governing bodies in charge of filling the gap when deficient aggregate demand occurs, so that the acquisition of material goods and the fruition of the enjoyments of life be not a privilege of the few but the conquest of civilization.
\end{abstract}

Keywords: Keynes, unemployment, crisis, General Theory

JEL Classification: E12, B21, B31

\footnotetext{
* Lecture delivered as Jean Monet Conference, in the Faculdade de Ciências Econômicas - UFMG in Belo Horizonte on June 1, 2017. An earlier and shorter version is published in Italian in Moneta e Credito, vol. 70 n. 277 (March 2017), pp. 7-19.

† Sapienza, Università di Roma. cristina.marcuzzo@uniroma1.it
} 
In the aftermath of the 2007-8 crisis, the name of Keynes has again entered the list of economists to be read, whose ideas are to be taken seriously. After over twenty-five years of ostracism, spent praising the efficiency of free markets and running econometric tests to prove that economic policies are either ineffectual or even irrelevant, there has been an upsurge in the wave of references to Keynes in the media. Unfortunately, this has not been reflected in the academic scene, still dominated by the macroeconomics of anti- or pre-Keynesian inspiration that took hold between the 1970s and 1980s.

To reclaim the topical importance of The General Theory of Employment, Interest and Money, I would like to begin by pointing out how the space assigned to government intervention has shrunk in contemporary public opinion; it was the "policy space" opened up by Keynes's denunciation that market laws are neither natural nor unchangeable. The guiding spirit of the Keynesian Revolution is that full employment is a goal which can be pursued not by following the free market rules, but by reshaping them by means of public intervention. This message was widely accepted for thirty years as from the end of the Second World War by all the advanced countries which actively engaged in full employment and welfare policies, and subsequently abandoned with the neo-liberal Restoration which saw the dogmas of individualism and de-regulation prevailing.

In reclaiming the topical importance of the General Theory, we should of course take into consideration the changed circumstances of today's world when compared to those of twenty - let alone eighty - years ago, although there are notable similarities between the Great Depression of the 1930s - Keynes's world - and our contemporary crisis ${ }^{1}$. A corresponding similarity is to be seen between the economic theory prevailing before Keynes's times and that of our own times. (See Wray 2013).

The return to Keynes I would like to see, arguing for its topical relevance, is firstly in the realm of method. In a famous letter to George B. Shaw, written a few weeks before the publication of the General Theory in February 2016, Keynes announced it as a book "which will largely revolutionise [...] the way the world thinks about economic problems" (CWK XIII: 492). And in the same letter he added:

"When my new theory has been duly assimilated and mixed with politics and feelings and passions, I can't predict what the final upshot will be in its effect on action and affairs. But there will be a great change" (CWK XIII: 493).

Rather than invoking the "scientific" aspect of his theory, Keynes turned to "politics and feelings and passions", to anticipate how his message would be received. A couple of years later, in a letter to Roy Harrod, recalling the story of Newton's discovery of the law of gravity on observing an apple fall to the ground while sitting in the garden of Trinity College, Cambridge, Keynes listed the questions that an economist should be asking: for instance, whether

"the fall of the apple to the ground depended on the apple's motives, on whether it is worth while falling to the ground, and whether the ground wanted the apple to fall, and on mistaken calculations on the part of the apple as to how far it was from the centre of the earth" (CWK XIV: 300).

Economics - Keynes wrote - "deals with introspection and with values [...] it deals with motives, expectations, psychological uncertainties' (CWK XIV: 300), whose scope is neither "constant nor homogeneous". There cannot be an analogy with physical sciences, because they aim at discovering regularities from which to derive general laws, while economics is expected to capture the effects of decisions taken in an uncertain environment and with

${ }^{11}$ See Sylos Labini (2009), Temin (2010), Shapiro (2012) and Eichengreen (2012). 
different degrees of information. So the object of economic theory is that of developing a logical way of thinking about factors, which are "transitory and fluctuating." (CWK XIV: 297).

When Keynes states in the General Theory that the level of employment oscillates around "an intermediate position" below full employment and above the minimum subsistence employment (CWK VII: 254), he explains that this position "is a fact of observation concerning the world as it is or has been, and not a necessary principle which cannot be changed" (ibid). The point made here is that in economics

"we cannot hope to make completely accurate generalisations" (ibid.) because the economic system is not ruled by 'natural forces' that economists can discover and order in a neat pattern of causes and effects. The task of economics, according to Keynes, is rather to "select those variables which can be deliberately controlled and managed by central authority in the kind of system in which we actually live" (ibid.).

Keynes's critique is directed against a conception of economics as scientific study of society modelled on the method of the physical sciences, and it is a plea to start investigating the problems involved in seeking to bring about desired end states. Only by exposing the fallacy of the analogy of economic laws with physical laws does it become possible to promote values and attitudes to change society. Keynes wrote:

"it is many generations since men as individuals began to substitute moral and rational motive as their spring of action in place of blind instinct. They must now do the same thing collectively" (CWK XVII: 453)

Letting individuals be guided by self-interest alone -as in Adam Smith's parable of "the butcher, the brewer and the baker", whose pursuit of individual profit produces a social good is not a principle of general validity, because there are not always forces to harmonize individual interests and, moreover, aggregate economic behaviour does not have the same outcome as individual economic behaviour. If the goal is to change the environment within which individuals operate, we ought to change the way we see the economic problem. This could be achieved, according to Keynes, through the power of persuasion. In a letter to T.S. Eliot of 5 April 1945, he wrote:

"[...] the main task is producing first the intellectual conviction and then intellectually to devise the means. Insufficiency of cleverness, not of goodness, is the main trouble [...] the full employment policy by means of investment is only one particular application of an intellectual theorem. (CWK XXVII: 384)".

And earlier on, in a famous speech to the House of Lords on May 23, 1944, he wrote:

"[for the last twenty years] I have spent my strength to persuade my countrymen and the world at large to change their traditional doctrines and, by taking better thought, to remove the curse of unemployment" (CWK XXVI: 16).

Clearly, by "better thought", Keynes meant a theory which, among other things, made the elimination of unemployment possible, rejecting the doctrine that whatever unemployment there is - as long as it is market generated - is a level which the same market forces - if unimpeded by "rigidities" (any of these: prices, wages, interest rate) would re-establish in the long run. This is the reason why in modern macroeconomics this level has been labelled as "natural".

In the aftermath of the Second World War we witnessed a transformation of economic theory into a set of models which, although at the cost of extreme simplification, were thought able to capture the fundamentals of the economic system they were describing; it was believed that models enabled empirical verifications of the variables and offered the means to provide the tools for policy intervention. 
The stress on forecasting, measurement, empirical testing was meant to enhance the scientific aspect of economics, where "scientific" again implied resemblance to the physical science, to their rigour and predictive power.

After Lionel Robbins (1932) had declared that ethics and political philosophy considerations should be banned from economic theory, Karl Popper in the 1930s (Popper [1935] 1959) vindicated the idea that economics could be a science only if value-free and with predictive power.

In the following two decades Friedman's insistence on prediction as the only test for economic theories and Samuelson's mathematization of economics gave a new boost to the faith in imitation of the physical sciences as far as the chosen method of scientific inquiry is concerned.

It is now apparent that this conception of what constitutes a good economic theory has not proved reliable, having had - especially in the recent crises - many examples of the inadequacy of mainstream theory in understanding let alone predicting forthcoming events. If facts are identified with empirical estimates of models that are believed to incorporate the progress made in the economic literature, it is clear that these "facts" are heavily dependent on the choice of the models and the methodology employed to find them. The relationship between facts and theory becomes opaque and we may reasonably challenge the motives behind the discovery of "facts", for they tend to be recognized or ignored according to the ebbs and flows of academic fashions. Let me take an example that is recent history.

My example is the multiplier - the heart of the Keynesian theory of effective demandwhich has a story of alternate acceptance and rejection in its over 70 years of existence. It is a formula telling us that every increase in autonomous expenditure (for instance private or public investment or exports) generates - through induced expenditure (net consumption, i.e. allowing for taxation and imports) - an increase in income greater than the initial expenditure, provided there are capacity underutilisation and unemployment. This is why the formula is called the "multiplier", because typically it gives a number greater than 1 .

Deficit spending, i.e. a level of public spending greater than tax revenue - is justifiable on two counts: a) because it creates income; $b$ ) because it generates the savings and tax revenues (both functions of the level of income) necessary to finance the initial investment. The consensus on this proposition lasted for almost 30 years until it was seriously challenged by the Monetarist assault of the late sixties. Building on his (and Franco Modigliani's) earlier work on the consumption function, Milton Friedman, on the basis of empirical estimate, showed that the independent variable in the consumption function was not current income, but income that can be assumed to be perceived as permanent over an individual life-time.

When consumption is made a function of permanent rather than current income, the value of the multiplier becomes much smaller, with the result that the whole idea that an increase in autonomous expenditure is expansionary was lost, sowing the seeds for mistrust of fiscal policy as a means to reach full employment. This, which came to be named The Monetarist Counterrevolution, was taken further by Robert Lucas and the New Classical economists well into the 1990s, meeting with feeble defence by the New Keynesians, who relegated the efficacy of the multiplier to the very short period, when prices and wage rigidities prevented the system from getting into full employment equilibrium.

Until the outbreak of the 2007-8 crisis the majority of the economic profession in prestigious universities and institutions such as the World Bank and the IMF, and in influential media such as the Financial Times and the Economist, agreed that the scant value of the multiplier was conclusive proof of the limited or even null impact of public expenditure on the 
level of income and employment. The classical arguments against short-term policy interventions - the lags in making economic policy and further lags in the implementation and effects after the policy is enacted - coupled with the assumptions on the countering effects of expectations and actions of rational agents who observe the government's policy process, had made it appear practically impossible for policymakers to time fiscal policy actions to jumpstart the economy.

In the 1950s and 1960s, when Keynesianism was at its height, the multiplier was generally assumed to be about 2 (two). Then, in the 1990s and 2000s, these estimates gradually dropped, leaving the consensus range about 0.5-0.7. However, the value of the multiplier was again closer to 1 after the crisis. In fact, in 2009 the estimates by both the IMF and the European Union showed the value of the multiplier in the range of 0.9 and 1.7 (Marcuzzo 2014). At last the multiplier is multiplying again, since it cannot be denied against the evidence of the effects of drastic cuts in public expenditure brought about by austerity programmes in Europe.

This is just one example of how empirical evidence to a great extent depends on the nature of the models that are constructed to find it, and also on the behavioural assumptions embedded in these models. In orthodox economics, consumers are said to pursue their individual maximizing utility over an infinite time horizon and with full knowledge of possible outcomes and perfect foresight. This is precisely the opposite of consumer behaviour as viewed in Keynes's macroeconomics, where perfect foresight and full rationality are not deemed acceptable assumptions, because probability calculus is not applicable: when there is uncertainty, as is the case in human affairs in general and in economic matters in particular, such calculation is not feasible.

The assumption of perfect foresight was discredited after the events of 2007-8. This meant bringing some modifications into the standard macro-models to incorporate limited rationality and knowledge, imperfections and rigidities in the goods, labour and financial markets. However, these modifications were made within a theoretical apparatus which remains unchanged in its main features and, in any case, still quite the opposite of the way Keynes understood and described economic behaviour, which was never imputed to abstract economic agents, but always to individuals who have specific functions and characteristics.

Consumers, entrepreneurs or speculators always make their decisions in the face of uncertainty; therefore, according to Keynes, their behaviour cannot be described as guided by an optimizing rationality, as the utilitarian tradition would have it. Economic choices require evaluation of the available information, which is often contradictory or ambiguous and most of the time insufficient to offer enough elements to predict the future course of events. In each specific case the evidence we collect bears different "weight" in the argument we use to make our choices, on the basis of our knowledge and experience.

However, decision-making in a context of uncertainty should not imply the impossibility of making decisions according to reason, although the reason involved here is not the rationality employed in orthodox economic theory. Keynes was not only a great economist, but an investor on a large scale, for himself, his college and insurance companies; at King's College Archives, several unpublished papers document his investment strategy and philosophy, showing how painstakingly he collected and carefully reviewed all the evidence before making his choices (Cristiano and Marcuzzo 2018).

Keynes's rationality - which is not to be confused with optimizing choice - should be interpreted as "reasonableness", a concept describing the attitude to adopt in situations where following the rationality implied by economic theory might lead to very unsatisfactory outcomes. Keynes refers to it when dealing with the questions of the War Reparations 
imposed on Germany, insisted upon by the victorious powers after the First World War, and again in the negotiations on the repayment of loans to Great Britain made by the United States during the Second World War. And the question continues to arise: was it "reasonable" not to rescue Lehman Brothers but to let it go bankrupt?

So far I have been arguing on the relevance of the General Theory as a revolution in economic thinking; now I would like to move on to a more specific issue, namely when and whether government intervention is called for to correct market forces, since this is what is usually, and in an unqualified way, understood as the Keynesian message.

Adam Smith had already shown how rules and limitations are needed to prevent market failures: on defence, education and other "public goods" the market simply does not deliver the best. This is not the crux of the matter in the case of Keynes's subversion of the mainstream approach, but rather the role of effective demand in generating, income, increasing production and guaranteeing employment. It is the low level of effective demand, not the rigidity of money wages, which accounts for underemployment equilibrium.

Contrary to the opinion of the mainstream economists, Keynes does not assign to prices (wages and interest rate included) the task of adjusting supply and demand to bring the system to full employment equilibrium. Only by supporting a high level of demand, through policies designed to do so, can this goal be attained.

However, Keynes was not in favour of indiscriminate deficit-financed public investments: in the General Theory we do find an apology for government intervention, but this is to be interpreted in terms of the need to control the total level of investment, through direct or indirect action by a public or semi-public body, always taking into account market incentives, and favouring a climate of business confidence. This is clearly spelt out by Keynes:

\footnotetext{
"If the State is able to determine the aggregate amount of resources devoted to augmenting the instruments and the basic rate of reward to those who own them, it will have accomplished all that is necessary" (CWK VII: 378).
}

Similarly, on the origin and structure of the welfare state, Keynes's ideas were not represented faithfully (see Backhouse and Bateman 2012). He was not in favour of high taxes to pay for social benefits and pensions, the costs of which ought to be borne by the employers, whose interest was to have a fit and healthy labour force (CWK XXVII: 224). He was in favour of making the State accountable to the taxpayer for the goods and services provided, associating "as closely as possible the cost of particular services with the sources out of which they are provided", for he believed that "this is the only way by which to preserve sound accounting, to measure efficiency, to maintain economy and to keep the public properly aware of what things cost" (CWK XXVII: 225).

He helped Beveridge to draft the Social Insurance and Allied Services, the 1942 Beveridge Plan, as it was called, and gave his support it to having it approved. Keynes was appreciative of the "new features" of Beveridge's Plan, namely "the extension of the social security benefits and contributions to the whole of the population, and not merely to the present contributory classes" (Keynes CWK XXVII: 252), but he was concerned about the budgetary aspects of it. However, while both Keynes and Beveridge were preoccupied with the moral and social problems deriving from unemployment, they looked for solutions along different paths. For Beveridge, it was the human fight against scarcity, the plague of cycles in production and business confidence - as unpredictable as weather and natural calamities, as he saw them (Harris [1977] 1997). Social insurance was meant to disjoint individual coverage from general economic performance. Keynes, on the other hand, thought that by making the future dependent on the economic success of an active social investment policy it would be possible to free individuals from the deprivations deriving from unemployment. 
Keynes did not believe in the idea embraced by Malthus and Mandeville that opulent consumption by the rich provided the source of income and employment and, therefore, the key to economic growth. In the General Theory consumption is seen as the necessary means for the well-being of society; the propellant, so to speak, in the machinery to boost employment and income. However, Keynes sees two major problems related to consumption. The first is satiation, which he believed derived from a "fundamental psychological law", according to which "men are disposed, as a rule and on the average, to increase their consumption as their income increases, but not by as much as the increase in their income" (CWK VII, p. 96). It follows that, since

"the larger our incomes, the greater, unfortunately, is the margin between our incomes and our consumption", the government must find ways to fill the gap, unless it accepts a level of unemployment sufficient "to keep us so poor that our consumption falls short of our income by no more than the equivalent of the physical provision for future consumption which it pays to produce to-day" (CWK VII: 105).

The second problem with consumption is how best to bring about the desired increase in the propensity to consume in order to sustain aggregate demand. The means could be found in a fiscal policy aiming at more equitable distribution of incomes (CWK XIV: 16), thereby increasing aggregate consumption. However, this is a policy that is bound to come up against opposition, and by no means easy to implement. Alternatively, fiscal policy can be directed to boosting aggregate consumption through public expenditure, entrusting the government with "the task of adjusting to one another the propensity to consume and the inducement to invest" (CWK VII: 380) or "making public investment a counterweight to fluctuations of private investment" (CWK XXVII: 381).

Keynes's love of paradoxes lies behind the famous example that, as Joan Robinson tells us, was meant "to penetrate the thick walls of obscurantism of the old laissez-faire orthodoxy" (Robinson 1964: 91). The suggestion was for the Treasury to bury bottles filled with banknotes and let private individuals lease the ground, dig out the bottles and pocket the money (CWK VII: 129). This is clearly a paradox, against the view that every operation should make a full profit or not be done at all. Keynes's makes his point - it does not matter how public money is spent, as long as it is spent, since it will generate income and, through the multiplier, the savings necessary to finance the initial expenditure - to illustrate a principle, not to provide a blueprint of "useful" public work schemes. Keynes spelt it out clearly:

'it would, indeed, be more sensible to build houses and the like; but if there are political and practical difficulties in the way of this, the above would be better than nothing' (CWK VII: 129).

The political difficulties mentioned by Keynes arise mainly from "the education of our statesman on the principles of the classical economics". Moreover, expenditure on useful goods and services may not always be equally practical: "Two pyramids, two masses for the dead, are twice as good as one; but not two railways from London to York" (CWK VII: 129). Moreover "unless the rate of interest is falling pari passu" with the marginal efficiency of investment there is a limit to the possibility of increasing the stock of wealth by means of "useful" forms of loan expenditure. Waste results not when expenditure is channelled to objects which are not "useful", but when they are not "economically" viable.

In Keynes's work we find many sarcastic comments on common prejudices against public spending, which can equally well be applied to today's defences of austerity programs. I would like to mention at least two:

"the man who regards all this [loan-financed public works, particularly public expenditure on housing] as a senseless extravagance which will impoverish the nation, as compared with 
doing nothing and leaving millions unemployed, should be recognized for a lunatic" (CWK XXI: 338).

And again:

"When we have unemployed men and unemployed plant and more savings than we are using at home, it is utterly imbecile to say that we cannot afford these things. For it is with the unemployed plant, and with nothing else, that these things are done. To have labour and cement and steel and machinery and transport lying by, and to say that you cannot afford to embark on harbour works or whatever it may be is the delirium of mental confusion" (CWK XIX: 765-766).

The two pillars of the Welfare State - distrust of market forces and, with it, reliance on government intervention to bring about full employment on the one hand, and lack of confidence in the power of liberalism to achieve economic security and social stability on the other, came from different traditions: Beveridge, the heir to the Fabians, relied on neoclassical economic theory, while Keynes, the revolutionary economist, relied on reformed liberalism for his social policy (Marcuzzo 2010).

Keynes's approach to the way to fight unemployment should not identified with the welfare state, nor with indiscriminate public spending, with no concern for the government budget, nor with attributing the causes of unemployment to the rigidity of wages and prices, nor indeed with all the other distortions of the General Theory we find in the literature, showing how little it was read or understood.

Keynes's message needs to be adapted to the present domestic and international circumstances, but it is still topical in its appeal to those common good values which markets are sometimes unable to deliver. Keynes was confident that addressing market failures was possible by placing in charge of institutions created for the purpose people - often chosen among his group of friends - who were of high moral standards and fortitude.

While Keynes rejected consequentialism in ethics, he endorsed consequentialism in his political philosophy, to the effect that rules have to be set for given goals. The relevant question becomes how these goals are chosen and how rigid or fixed these rules should be. Keynes rejected the abstract and formal character of rules, claiming that we should try to reduce the social damage caused by conventions and engage in substituting them with other, less socially harmful conventions.

It follows that, for Keynes:

"The reformer is not he who would impose his own values on society, but he who understands better than others the potential for change in the moral conventions of society itself, and acts in order to affect such change". (Carabelli and De Vecchi 1999: 291).

Two questions then arise: a) where does the "better understanding" of the reformer come from; b) which are the appropriate actions to change the moral conventions of society.

The answers to these questions are scattered among Keynes's early writings on ethics and politics and his mature work in economics, but they can also be gathered by reviewing his activities as policy adviser and even his practical experience in various institutions. It is in particular on the importance Keynes attributed to expert advice, to "superior knowledge", and his elitism that I mean to focus attention.

A good starting point is a passage from a famous letter to Hayek:

"Dangerous acts can be done safely in a community which think and feels rightly, which would be the way to hell if they were executed by those who think and feel wrongly" (CWK XXVII: 987-8). 
To think and to feel "rightly" or "wrongly" is contingent on two elements: knowledge and values. Skidelsky labelled Keynes "a meritocratic elitist" (Skidelsky 2009: 223), and he was not the only one to take this view. O'Donnell makes the interesting point that:

“Keynes's elitism [is] of an essentially intellectual variety, as distinct from those elitisms stemming from political, financial or military power. With individual varying in abilities, and with rationality linked to logical insight and knowledge, the presumption is strong that those with greatest mental power and education will have the greatest capacity in their given fields" (O' Donnell 1984: 66)

And he concludes that "Elitism is always a possible companion of intuitionist philosophy" (ibid). It was the belief in the rationality of ends as well as means that led Keynes to value "superior knowledge" as the guide to political actions. Superior knowledge can be acquired through experience and education, and only those who have acquired it can be entrusted with the management of affairs or enactment of reforms.

The rational pursuit of individual interest in economics, according to the utilitarian creed, does not guarantee the collective good, which Keynes identified with full employment. It is an assumption that leads to a logical fallacy, which Keynes identifies as the fallacy of composition. For instance, attempts to reduce real wages or increase the saving of individuals on the basis of an individual rationale will not achieve the aim if undertaken by all, since aggregate prevails over individual effect. Another example is when the level of aggregate demand is kept drastically low within a country to satisfy the reasons of the victor or creditor, leading to a deflationary potential for all the economies. Thus, lack of reasonableness leads to consequences not only morally reprehensible but also economically disastrous for anyone who has sought guidance solely from the individual point of view.

In Keynes's economics the impasse of failure to achieve the aggregate effect of full utilisation of resources can be remedied with a set of direct and indirect instruments designed to overcome individual inertia and generate the level of demand necessary to raise the level of employment. Much has been written on the extent to which Keynes endorsed state intervention (Marcuzzo 2010, Backhouse and Bateman 2012). It is worth recalling the main points here.

Keynes's argument is summarized in the need for fiscal stimulus to boost the economy from the depths of recession; the burden of the deficit is not seen as the main drawback for government intervention, but as a condition necessary to address a failure in aggregate demand. This argument does not, however, imply unqualified government intervention. Government expenditure is to be finalised to provide enough investment to counterweight a decline in private investment and a level of consumption insufficient to generate the level of aggregate demand necessary to maintain full employment.

Although Keynes's mistrust of the smooth working of market forces came long before the General Theory, the case for intervention is made there forcefully in the case of aggregate demand failure. However, the policy message in the General Theory is to sustain the level of investment - more "stabilizing business confidence" (Bateman 1996: 148) than debt-financed public works. His reliance on "socializing investment" rather than fiscal policy aiming at smoothing out consumption levels over the cycle shows his concern for the size of the deficit and the importance attributed to market incentives to bring about the desired level of employment. "If the State is able to determine the aggregate amount of resources devoted to augmenting the instruments [of production] and the basic rate of reward to those who own them," he wrote in the General Theory, "it will have accomplished all that is necessary" (CWK VII: 378).

His "vision" of the future of capitalist society rested on the belief that freedom from 
economic constraints would allow the vast majority of the population to pursue happiness and enjoyment in their lives. "It is not any fear of a failure of physical productivity to provide an adequate material standard of life that fills me with foreboding," he remarked, addressing the House of Lords in February 1943:

"The real problems of the future are first of all the maintenance of peace, of international cooperation and amity, and beyond that the profound moral and social problems of how to organize material abundance to yield up the fruits of a good life" (CWK XXVII: 261)

Keynes rejected utilitarianism, both in ethics and politics, and he did not endorse consequentialism in his ethical philosophy, but he accepted it in his political philosophy, the purpose of which, he believed, was to provide reasons for action.

According to Keynes, the goal of an ethically rational society could be achieved by overcoming the economic and moral obstacles that encumbered contemporary society. For Keynes persuasion - the primary tool of political action - provided the means to given ends. These means were to be grounded in sound knowledge and experience, which are the basis of trust and confidence in expert advice and council. He wrote:

"The first condition of successful control and useful interference of whatever kind from above is that it must be done with knowledge" (CWK XIX: 643).

Keynes's view of economics, whereby full employment was the instrument or "social primary" means to a good life, was intertwined with his consequentialism in politics,

In conclusion, his prescription for a better society lies in setting rules and limitations in the market arena, not letting individual self-interest prevail, and putting some governing bodies in charge of filling the gap when deficient aggregate demand occurs, so that the acquisition of material goods and the fruition of the enjoyments of life be not a privilege of the few but the conquest of civilization. There are at least two reasons why the ideas put forward by Keynes in the 1930s are still relevant for the world of today. The first, and perhaps the most important, is the global recession which has been persisting since 2008-9 and even now is showing only a few timid signs of recovery, forcefully reminding us of the events which prompted Keynes to look for solutions to mass unemployment and economic disruption. The second is the still pervasive free-market ideology that inspired the policies and behaviour that played no small part in fuelling the crisis. The traditional remedies to cure the 1930 s recession - reliance on market mechanisms and balancing the budget - have been resurrected in the present times, and while criticism of the austerity policies is gaining momentum Keynes's arguments still fail to be widely and fully accepted. It is time we woke up to them.

\section{References}

Backhouse, R. and Bateman, B. (2012), "Keynes and the Welfare State", History of Economic Thought and Policy, 1(1), p. 7-19.

Bateman, B. (1996), Keynes's Uncertain Revolution. Ann Arbor: University of Michigan Press.

Carabelli, A. and N. De Vecchi (1999), "Where to draw the line'? Keynes versus Hayek on Knowledge, ethics and economics", Journal of the History of Economic Thought, 6(2), p.271-296.

Cristiano, C. and Marcuzzo, M.C. (2018), "John Maynard Keynes: The Economist as Investor", Review of Keynesian Economics, (forthcoming).

Eichengreen, B. (2012), "Economic History and Economic Policy", The Journal of Economic History, 72(2), p.289-307. 
Harris, J. [1977] (1997), William Beveridge. A Biography, 2nd ed. Oxford: Clarendon Press.

Keynes, J.M. (1971-1989), E. Johnson and D. E. Moggridge (eds), The Collected Writings of John Maynard Keynes (CWK), London: Macmillan.

CWK VII, The General Theory of Employment, Interest, and Money

CWK XIII, The General Theory and After: Part I, Preparation

CWK XIV, The General Theory and After: Part II, Defence and Development

CWK XVII, Activities 1920-2: Treaty Revision and Reconstruction

CWK XIX, Activities 1920-9: The Return to Gold and Industrial Policy

CWK XXI, Activities 1931-9: World Crisis and Policies in Britain and America

CWK XXVI, Activities 1941-6: Shaping the Post-War World: Bretton Woods and Reparations

CWK XXVII, Activities 1940-6: Shaping the Post-War World: Employment and Commodities

Marcuzzo, M.C. (2014), "Whatever happened to the Keynesian multiplier?" in R. Baranzini and F. Allisson (eds), Economics and Other Branches: In the Shade of the Oak Tree. Essays in Honour of Pascal Bridel, London: Pickering \& Chatto, p. 157-68.

Marcuzzo, M.C. (2013), "Re-embracing Keynes. Admirers, Scholars and Sceptics in the Aftermath of the Crisis", in T. Hirai, M. C. Marcuzzo and P. Mehrling (eds), Keynesian Reflections. Effective Demand, Money, Finance and Policies in the Crisis, Delhi: Oxford University Press, p. 3-23.

Marcuzzo, M. C. (2010), "Whose Welfare State? Beveridge vs Keynes" in R. Backhouse and T. Nishizawa (eds), No Wealth but Life: Welfare Economics and the Welfare State in Britain 1880-1945, Cambridge: Cambridge University Press, p. 189-206.

O'Donnell, R. M. (1989), Keynes: Philosophy, Economics and Politics. The Philosophical Foundations of Keynes's Thought and Their Influence on his Economics and Politics. London: Macmillan.

Popper, K. [1935] (1959), The Logic of Scientific Discovery, London: Hutchinson.

Robinson, J. (1964), Economic Philosophy, Harmondsworth: Penguin Books.

Robbins L. (1932), An Essay on the Nature and Significance of Economic Science, London: Macmillan.

Shapiro, N. (2012), "Keynes, Steindl, and the Critique of Austerity Economics", Monthly Review, 64(3), p.103-13.

Skidelsky, R. (2009), Keynes. The Return of the Master. Public Affairs: New York.

Sylos Labini, P. (2009), "Le prospettive dell'economia mondiale", Moneta e Credito, 62(245248), p. 61-89.

Temin, P. (2010), "The Great Recession and the Great Depression", NBER Working Paper, 15645, January.

Wray, R. (2013), "The Dismal State of Macroeconomics and the Opportunity for a New Beginning" in J. Davis and W. Hands (eds), The Elgar Companion to Recent Economic Methodology, Cheltenham: Eward Elgar, p. 452-72. 